\title{
Indonesia's Poverty Reduction: Driving Economic Growth through Foreign Direct Investment
}

\author{
Feny MARISSA ${ }^{1}$ \\ Sri ANDAIYANI 2 \\ Deassy APRIANI ${ }^{3}$ \\ Fera WIDYANATA ${ }^{4}$
}

\begin{abstract}
Poverty reduction is one of the basic problems in national development. One of the sources of financing in development programs including poverty reduction is foreign direct investment (FDI). Wherewith sources of that funds initiate an increase in the production of goods and services by the community so that transactions related to capital and production resources also increase as one of the efforts to alleviate poverty due to an increase in nominal income per capita. This study examines the indirect effect of FDI on poverty in Indonesia, through the analysis of numerical data calculations. This quantitative research on the State of Indonesia was carried out domestically using panel data from 34 provinces during the 2007-2018 periods with a fixed effect estimation method. The estimation results with the selected calculation model show that all independent variables are statistically significant. It means that the ratio of FDI to GRDP, the number of the working population, GRDP per capita, and the realization of government spending have a significant and negative effect on poverty with a confidence level of 5 percent. Based on the calculation results, if the ratio of FDI to GRDP increases by 1 percent, it will reduce the poor by 0.037 percent, (ceteris paribus). This finding encourages the government to pay more attention to the flow of foreign investment into Indonesia so that funding is more targeted in reducing poverty in Indonesia. Through the provision of employment opportunities and improvement of supporting facilities, productivity can run more efficiently and effectively.
\end{abstract}

KEYWORDS: foreign direct investment, poverty, fixed effect model.

JEL CLASSIFICATION: E22, I32

\section{INTRODUCTION}

Poverty is one of the fundamental problems in developing countries such as Indonesia and it can be one of the inhibiting factors in the process of economic growth, arising from the inability of some people to organize their lives to a level that is considered human. an area and disrupt the level of community welfare. It can be associated with physical and nonphysical conditions of the state, such as a lack of capital, malnutrition, large numbers of unemployed people, unsanitary housing, inadequate health services, low levels of education, and low per capita income. Although from year to year the percentage of poor people has decreased, this is still the focus of government attention.

\footnotetext{
${ }^{1}$ Universitas Sriwijaya, Indonesia, fenymarissa@fe.unsri.ac.id

${ }^{2}$ Universitas Sriwijaya, Indo-nesia, sriandaiyani@fe.unsri.ac.id, corresponding author

${ }^{3}$ Universitas Sriwijaya, Indonesia, deassyapriani@fe.unsri.ac.id

${ }^{4}$ Universitas Sriwijaya, Indonesia, ferawidyanata@fe.unsri.ac.id
} 
In absolute terms, the decrease in the number of poor people in the 2006-2013 period amounted to 745.3 thousand people, namely 29.29 people in 2006 to 28.55 million people in 2013. There was also a decrease in the percentage of poor people from 16.58 percent. in 2007 to 9.66 percent in 2018 (Figure.1)

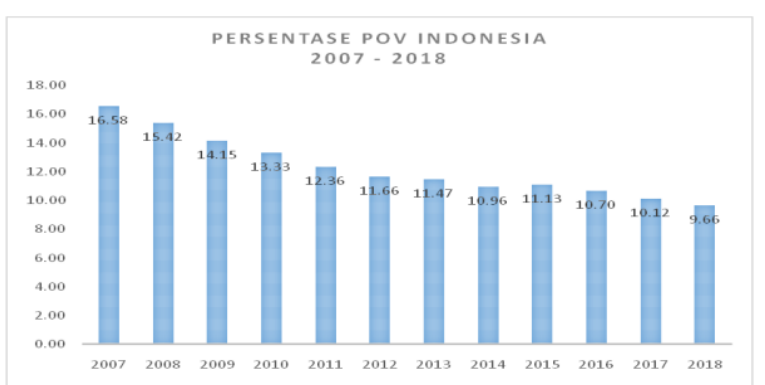

Figure 1. Percentage of Poor People in Indonesia 2007-2018

Source: adapted from BPS (reprocessed)

Various poverty reduction programs is done by the government, such as poverty reduction programs based on social assistance, community empowerment, empowering small businesses and etc, which are carried out by various elements of both central and regional governments In fact, not infrequently several groups of people who have a standard of living far above the average take part in social activities in the context of poverty reduction. All of these poverty reduction programs require substantial funds, while domestic development funds are still limited.

One of the sources of funding for Indonesia's development comes from foreign direct investment (FDI). FDI is one of the important things in the development of a country. Foreign direct investment can be a contribution from investors as an alternative source of funding which if the component increases, it will increasingly have an impact on reducing poverty levels, through the improvement of new technologies in destination countries, creating jobs in developing countries Blomström et al., (2003), as a source of economic development, modernization, income growth, job creation, and also poverty reduction Tambunan (2005). Foreign Investment encourages cooperation between domestic and foreign parties to increase trade expansion to the international zone. It is reflected in economic policies that are explicitly aimed at increasing foreign direct investment and at maximizing the benefits of foreign direct investment for the domestic economy. During the last two decades, Indonesia and the other countries have implemented economic reforms ranging from trade liberalization and privatization of state enterprises, which have an effect on the flow of foreign investment. According to Raeputranto (2017), the importance of foreign investment is one of the government instruments of ASEAN countries to create economic growth which will ultimately lead to poverty alleviation not exception in Indonesia.

Since the Asian financial crisis in 1997, Indonesia has become more liberal in its economic policies to attract more foreign direct investment to promote economic growth and reduce poverty, although it is not explicitly mentioned in its official policy statement. However, when it was compared to the period before the 1997 economic crisis, Indonesia was relatively less successful in attracting foreign direct investment despite an increase in the flow of foreign direct investment globally (Tambunan, 2005).

Although the impact of FDI on poverty in several developing countries has been identified, there has not been much empirical research on the effect of FDI on poverty in Indonesia. FDI can have a positive or negative effect on poverty. FDI can reduce poverty by creating new 
jobs, transfer of technology, increasing revenue taxes and economic growth. However, FDI may not affect poverty if foreign investors recruit too many educated and skilled workers who are not poor. Besides, FDI through foreign companies can compete with local companies so that it can make the poor population can be poorer because they cannot compete with foreign companies. Therefore, the role of the government is needed here as a monitor and director of applicable policies. With the hope that the allocation of foreign direct investment (FDI) is right on target to increase the productivity and standard of living of the lower middle class. Amertapama (2009) attempted to research the effect of FDI on poverty in Indonesia and each province from 1995-1999 by comparing it before and after the crisis. The results stated that before the crisis, FDI could reduce poverty, but after the crisis FDI inhibited poverty. However, when viewed from each of the periods, it does not reflect the effect of FDI on poverty because it is too short. Also, the influence of FDI on poverty for each province has not yet reflected the condition of the region because regional autonomy only started in 1999, where regions have certain powers in regulating their regions, including regarding foreign direct investment. For this reason, this study aims to look at the relationship between FDI and poverty in Indonesia, especially for each province in Indonesia. This study provides two contributions. First is to analysis the influence of FDI on poverty in Indonesia. Second is to provide about how different the intercept is for each province in Indonesia which the updated version after each local government has the authority to regulate their respective provinces with their creativity and innovation so that each region will display different effects of FDI on poverty. This percentage of the allocation of funds can be used to describe the accuracy and effectiveness of the use of FDI capital, so that Venar can actually reduce poverty, not even increase the wealth of people who have a quality of life above standard (fairly and equitable distribution of wealth).

\section{LITERATURE REVIEW}

Several researchers have examined the relationship between FDI and poverty. Some of them investigated the relationship between FDI and poverty in developing countries because poverty often occurs in developing countries. Aaron (1999) investigates how FDI contributes to poverty reduction in developing countries and what policies developing countries should adopt in maintaining and increasing this contribution. He breaks down the relationship between FDI and poverty reduction into two parts, the first is the relationship between FDI and economic growth and the second is the relationship between growth and poverty reduction. Aaron classified the effect of FDI on the economy of the destination country into direct and indirect effects. FDI can indirectly create job opportunities with a multiplier effect of 1.6, which means that FDI can indirectly create 8 job opportunities for every 5 job opportunities that are created directly. Aaron also claims that FDI can increase women's work participation where it can increase household income. However, the wages of female workers are still lower than the wages of male workers. Besides, FDI can create technology transfer to destination countries through licensing and subcontracting activities. FDI can increase human capital in the destination country which can be formed directly through foreign companies in the destination country and indirectly through externalities in developing the capacity of workers.

Klein (2003) argued that FDI is an integral component of the success of economic growth in developing countries. In their study, they claim that economic growth is a key factor in poverty alleviation, and FDI is considered the most important asset for reducing poverty. According to this study, in addition to its stimulating effect on growth, FDI can improve the quality of economic growth and help reduce poverty. There were several conditions for DI to 
be successfully implemented and to reduce poverty. Some of the conditions are providing the right environment for foreign investors, providing equal protection between domestic investors and foreign investors, and the existence of government regulations that are not arbitrary and do not burden foreign investors. They believe that FDI helps reduce income poverty by promoting economic growth.

Hung (2005) investigated the impact of FDI on growth and poverty reduction with regression analysis using 1992-2002 panel data in 12 provinces and cities in Vietnam. Like Aaron (1999), Hung considers the relationship between FDI and poverty reduction to be twofold. First, FDI inflows in provinces have a positive effect on regional economic growth. He also revealed that there is a negative correlation between economic growth and the number of people living below the poverty line. Amertapama (2009) using data for the period 1995-2005 and using the dummy before and after the crisis proved that FDI had a significant effect on poverty. Before the crisis, FDI was able to reduce poverty, but after the crisis FDI inhibited poverty. It is due to an unstable political condition where there were riots and demonstrations in Indonesia so that investor confidence was reduced.

According to Blomström et al., (2003) and Blomstrom and Kokko (1997), the contribution of FDI to country expansion is widely recognized as filling the gap between desired investment and destination domestic savings, increasing tax revenues, and improving management and technology, also skills of the host country workforce. Which can help the country to reduce poverty (Blomstrom \& Kokko, 1997). Based on the Neoclassical theory, FDI can affect income growth by increasing the amount of capital per individual. FDI can influence longterm growth by increasing human capital and developing research and development (R\&D). In addition, it can affect technology transfer to affiliated companies and technology externalities in companies that are not affiliated with the economy of the destination country. This can accelerate the development of new product variations, improve product quality, and facilitate international cooperation in $\mathrm{R} \& \mathrm{D}$, and introduce new forms of human capital (Ikara, 2003).

FDI can have a direct impact on poverty through the provision of job opportunities, namely the provision of jobs and training for workers. Foreign direct investment can increase capital for the government in building public works projects such as road construction, power plants, ports, irrigation, communications, and others. This will increase employment opportunities for each individual and absorb a lot of labor also will ultimately reduce unemployment. People's incomes will increase and will reduce poverty levels (Chudnovsky \& López, 1999; IFC, 2000; Raeputranto, 2017).

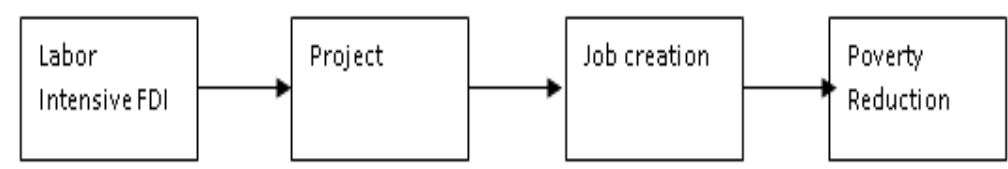

Figure 2. The transmission mechanism between FDI and Poverty through Job Creation

Furthermore, FDI has an impact on poverty reduction through tax revenues from foreign subsidiaries in Indonesia. Tax revenue will increase government revenue. The government budget will be used to finance development programs, including increasing productivity and developing labor-intensive economic activities (such as industry and agriculture) or other poverty alleviation programs (Klein, 2003). 


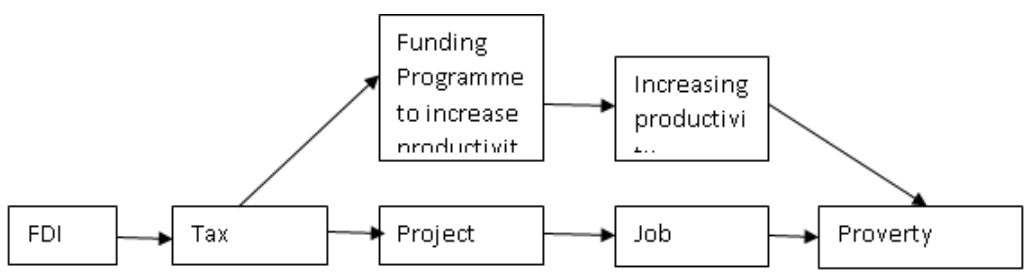

Figure 3. The transmission mechanism between FDI and Poverty is through Income Tax Receipts

The impact of FDI on poverty can be indirectly through the contribution of FDI to economic growth, namely by increasing the role of economic growth in poverty reduction (IFC, 2000); (Dollar \& Kraay, 2004). (Hung, 2005) states that FDI can affect economic growth through increasing capital, that is, providing external finance and can help reduce financial barriers to investment. (Ikara, 2003) shows that FDI can reduce poverty by increasing the total factor of production and the efficiency of the resources used. This will lead to economic growth and will ultimately reduce poverty. He emphasized the transmission mechanism between FDI and poverty reduction through direct technology transfer, technological externalities, increasing human resources, international trade integration, and a competitive business environment. (Blomstrom \& Kokko, 1997) argue that FDI will lead to new technology, management, and marketing capabilities. FDI causes the transfer of technology to the destination country through the transfer of physical goods, the transfer of knowledge consisting of new techniques or skills, technical and organizational capabilities. Through FDI, there will be more new technologies, innovations, knowledge, and tangible assets that can be applied to destination countries so that it will increase productivity and increase workers' abilities or skills. This will result in increased employment opportunities, especially for a productive workforce, and an increase in company productivity. Furthermore, people's income will increase and will reduce poverty.

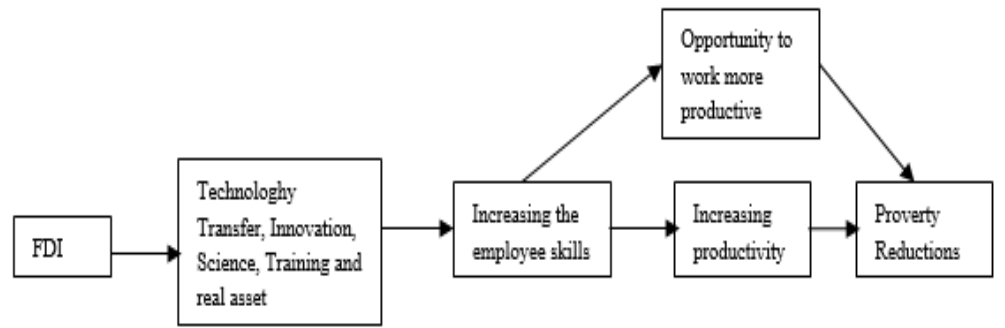

Figure 4. The transmission mechanism through Technology Transfer

\section{METHODOLOGY}

This study uses secondary data from 34 provinces over a 12 years period, from 2007 to 2018 which were obtained from the Central Statistics Agency. The data used are the percentage of poor people by province, foreign direct investment (FDI) by region (in \$ million), Gross Regional Domestic Product (GRDP) per capita at constant prices by region (in thousand rupiahs), the number of people who are 15 years old. Those who worked during the past week by province realized government spending by region (in thousand rupiahs). Foreign direct investment is referred to here as direct investment funds that are used to carry out business activities or purchase production facilities such as buying land, establishing factories, buying machinery, buying raw materials, and so on. This term is deliberately created to distinguish it from portfolio investment where investment funds are not directly used for business activities, namely to buy stocks, bonds, and other securities (Todaro, 1990). In the model, the FDI used 
is the ratio between FDI (\$ million) and GRDP at constant 2000 prices (million rupiahs) multiplied by the rupiah exchange rate against the dollar at the end of the year concerned. The model used in this study adopted the Hung (2005) model. In general, the model can be written as follows:

$$
\mathrm{POV}_{\mathrm{i}, \mathrm{t}}=\square_{\mathrm{i}, \mathrm{t}}+\mathrm{FDI}_{\mathrm{i}, \mathrm{t}}+\mathrm{PDRBkapita}_{\mathrm{i}, \mathrm{t}}+\mathrm{EMP}_{\mathrm{i}, \mathrm{t}}+\mathrm{EXP}_{\mathrm{i}, \mathrm{t}}+\square_{\mathrm{i}, \mathrm{t}}
$$

Where POV is the percentage of poor people, FDI is the ratio of foreign direct investment to Gross Regional Domestic Product at constant prices, GRDP per capita is the Gross Regional Domestic Product divided by the number of residents of the province concerned. PDRB per capita used here is GRDP without oil and gas per capita at constant 2000 prices. EMP is the number of people aged 15 years and over who worked during the past week, and EXP is the amount of government expenditure. The units or quantities of data used in this model are quite diverse. The PDRB per capita in thousand rupiahs and government expenditure in thousands. This calculation and analysis model was chosen because it was judged to be in accordance with the purpose of the study which wanted to see the effect of foreign direct investment (FDI) on poverty levels, because all inputs and outputs of production activities resulting from foreign capital invested directly in the community were listed as variables in the this model. Several previous studies also used this calculation model to see the results in the form of numbers or percentages to be analyzed. The suitability of the kiga model selection will be tested using several tests, such as the Chow test, LM test, and Hausman test. This model can clearly capture the differences in the intercepts of each entity and for any given time period, so that the results of the estimated influence between the variables sought can be depicted accurately and the results can be trusted. The regression model also allows control of the level of heterogeneity of the data, providing more variability, more degrees of freedom, efficiency, and low levels of collinearity between variables (Ucal \& Meltem, 2013). For data uniformity, the FDI, GRDP, EMP, and EXP data are formed in natural logarithms. However, the POV variable is not transformed into a natural logarithm because it is already in the form of a percentage. According to Nachrowi and Usman (2004), data transformation using logarithms is intended to reduce the scale between independent variables. If the range of observed values is 'narrow', it is expected that the error variation will not differ greatly across the observation groups. This study will use panel data regression. (Ahmad et al., 2019) used real GDP per capita as the dependent variable to investigate the relationship between FDI and welfare. While (Magombeyi \& Odhiambo, 2018) using the Autoregressive Distribution Lag (ARDL) Boundary Test on cointegration and error correction models to investigate the relationship between FDI and poverty. The ARDL approach for strong cointegration in small samples so it is not appropriate to use it in this study.

The estimation method used in this research is the panel data method. There are three kinds of approaches, namely the least square approach (pooled least square), the fixed effect approach, and the random effect approach. The parameter estimation in this study uses a fixed effect approach model because this model assumes that the differences between individuals can be accommodated from the differences in the intercept. Previously, in choosing which model is most suitable to be used, the F test was first carried out to choose the best between Pool with Fixed Effect, and then the Hausman test was carried out to choose between Fixed Effect and Random Effect Models. 


\section{RESULT AND DISCUSSION}

Based on Figure 1. In general, the percentage of poor people from 2007 to 2018 has decreased, namely 11.22 million people. Even though the percentage of poverty fell, the number of poor people continued to increase. Based on (Figure 1) also, the percentage of poor people in Jakarta is the lowest compared to other provinces in the 2007 - 2018 period, while the Papua province has the highest percentage of poor people among other regions in the 2007 - 2018 period. In 2018, 5 regions the ones who occupied the highest poverty level were Papua at 27.74, West Papua at 23.01, NTT at 21.35 percent, Maluku at 18.12 percent, Gorontalo at 16.81 percent. The percentage of poor people fluctuates in each province, for example in Jambi the poverty rate in 2012 was 10.53 percent, decreased by 10.4 percent in 2013, then in 2014 , the poverty rate increased by 10.67 percent. The same thing happened in several provinces in Indonesia.

The highest percentage of poor people in 2007 was in West Nusa Tenggara at 30.44 percent, for the lowest percentage of poor people was in South Kalimantan and Bali at 06.1 percent. The highest percentage of poor people in 2015-2018 was in West Nusa Tenggara Province while the lowest percentage of poor people in 2015 was in North Maluku province at 2.61 percent. The highest percentage of poor people in 2018 was in West Nusa Tenggara Province at 15.66 percent, for the lowest percentage of poor people was in Bangka Belitung province at 2.78 percent.

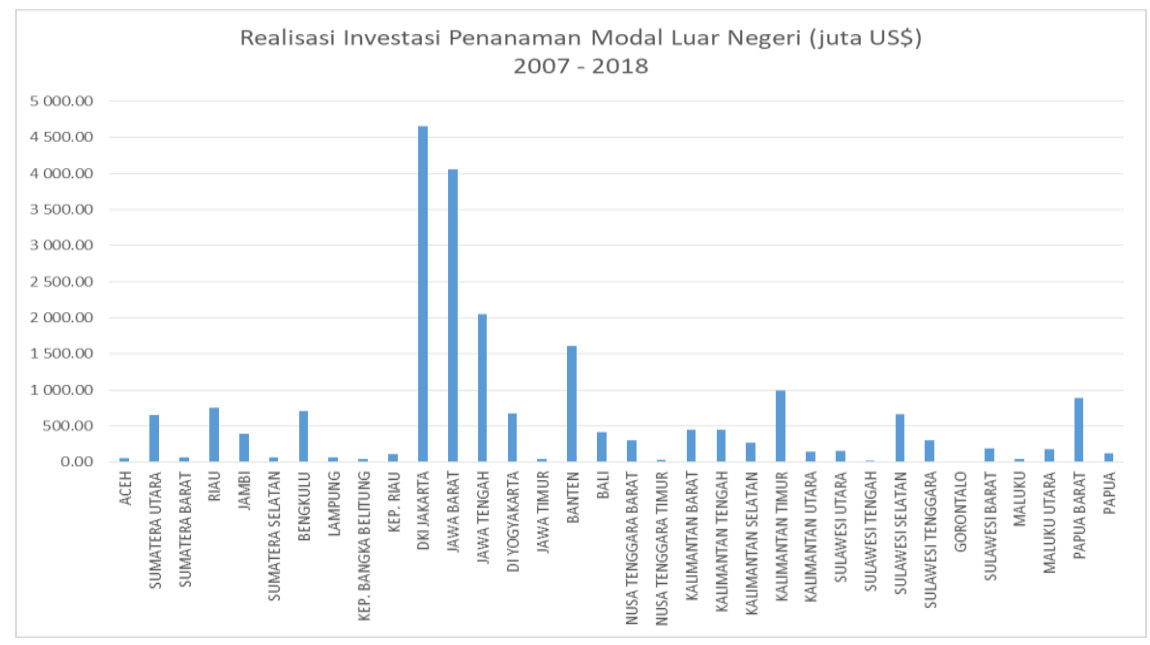

Figure 5. The averages of FDI by Provinces

Source: adapted from BPS (reprocessed)

The amount of FDI also fluctuates every year. For Indonesia, FDI was \$ 14.87 .4 million in 2008. However, in 2009 there was a decrease in FDI in Indonesia, namely by $\$ 10,815$ million. This was due to the financial crisis in 2008 as a result of the financial crisis in the United States in 2008 due to the subprime mortgage. This resulted in many investors withdrawing their funds due to economic instability. however, after 2009, FDI continued to increase until 2018, amounting to $\$ 28,617$ million. The amount of FDI received for each province also varies. As shown in figure 2.1, the province that received the most FDI for 2007 to 2018 was DKI Jakarta, this is because DKI Jakarta is the capital of Indonesia but the increase in investment realization in DKI Jakarta is inseparable from the various service innovations that are continuously being presented by the Provincial DPMPTSP. DKI Jakarta is providing approach and service convenience in the investment sector. Then followed by West Java Province, West Java is a satellite city so that many businesses and investments 
develop in the city. However, when viewed from the ratio of FDI to GRDP, the province with the highest average during the 2007-2018 period was West Papua province, amounting to 0.515. This indicates that in West Papua, incoming FDI is half of the GRDP. Many investors invested their funds there because of the extraordinary potential of West Papua. There is a Raja Ampat tourist attraction that attracts many foreign and domestic tourists so that many investors are interested in investing or developing their business there. Meanwhile, the lowest average ratio of FDI to GRDP is in the province of East Java. This is because the FDI that comes in East Java is relatively smaller than that of other provinces. As shown in (Figure 5).

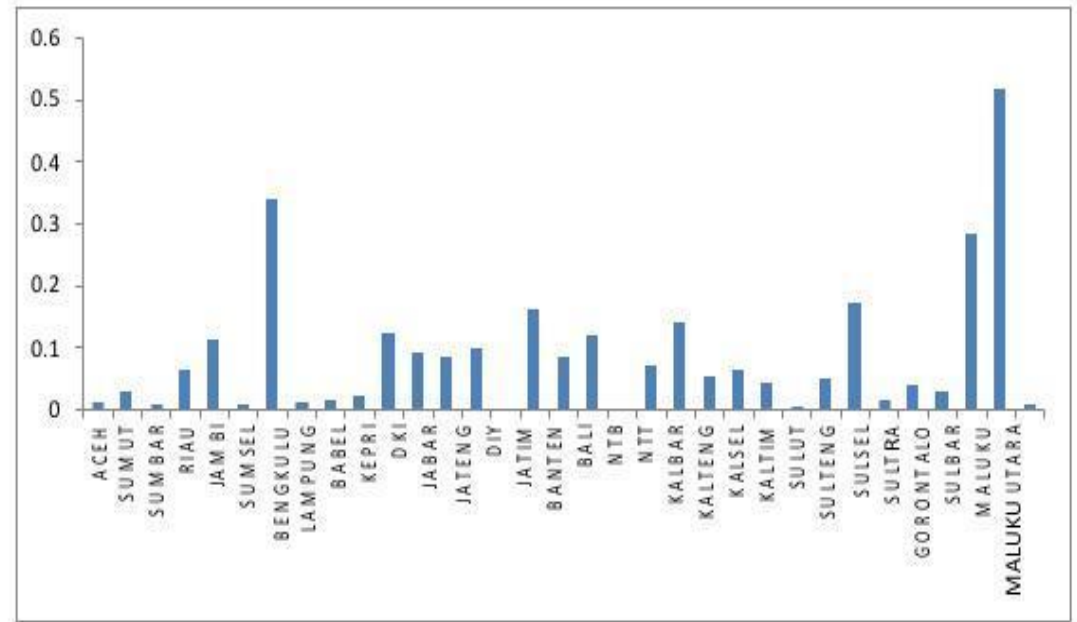

Figure 6. The Avarages of FDI to GDP by Provinces Source: adapted from BPS (reprocessed)

The basic consideration in choosing the best model is by performing the Chow test, Lagrange Multiplier (LM) test, and Hausman test. With a confidence level of 5 percent, based on the Chow Test (to choose a model between common effects and fixed effects), it can be seen that the probability value is less than $\alpha=5 \%$, so $\mathrm{H} 0$ is rejected, meaning that the appropriate model is a fixed-effect model.

Table 1. The Result of Chow Test

\section{Redundant Fixed Effects Tests}

Equation: Untitled

Test cross-section fixed effects

Effects Test

Cross-section F

Cross-section Chi-square
Statistic

71.873011

836.13800930

Source: Data Processed d.f.

$(34,376)$

34
Prob.

0.0000

0.0000

The test is continued with the LM test to choose the right model between the common effect model and the random effect model. Based on the LR test, the appropriate model is the random effect model. The test is continued with the Hausman test to determine the right model between the fixed effect or random effect. Based on the Hausman test, the probability value is less than $\alpha=5 \%$, so that $\mathrm{H} 0$ is rejected, meaning that the appropriate model is a fixed-effect model. 
Table 2. Hausman Test

Correlated Random Effects - Hausman Test

Equation: Untitled

Test cross-section

random effects

Test Summary

Chi-Sq. Statistic

Chi-Sq. d.f.

Prob.

Cross-section random

13.847780

4

0.0078

\section{Source: Data Processed}

Based on the results of the three tests, the correct model is the fixed effect model. The fixed effect model used in this study is a weighted fixed effect model (cross-section weights) to overcome the problems of heteroscedasticity, multicollinearity, and autocorrelation. To get a BLUE estimator (Best, Linear, UnPure Estimator), this estimator must be free from violations of classical assumptions, namely multicollinearity, autocorrelation, and heteroscedasticity. The estimation results in the fixed effects model (table 6.3) show that all the independent variables are statistically significant. It means the ratio of foreign direct investment to GRDP, total working population, per capita GRDP, and realization of government spending have a significant and negative effect on poverty with a confidence level of 5 percent. The model used can describe 97.79 percent of the existing diversity.

Based on the above results, it is evident that foreign direct investment harms poverty. The higher the ratio of FDI to GRDP, the lower the percentage of poor people will be. Based on the calculation results, when the ratio of FDI to GRDP increases by 1 percent, it will reduce the poor by 0.037 percent, assuming the other variables are constant (ceteris paribus). FDI is used maximally by the government in terms of poverty alleviation. When FDI increases, investment recipient regions will get benefits such as additional capital in the production process and efficiency and effectiveness at work, to encourage the economy in the province concerned and reduce poverty, among others, through the provision of jobs and improved facilities

Table 3. Estimation Results

\begin{tabular}{lllll}
\hline Variable & Coefficient & Std. Error & t-Statistic & Prob. \\
\hline C & 13.98216 & 1.224928 & 11.41468 & 0.0000 \\
FDI & -0.000376 & 0.000167 & -2.249906 & 0.0250 \\
PDRBKAPITA & $-2.37 \mathrm{E}-05$ & $6.52 \mathrm{E}-06$ & -3.637071 & 0.0003 \\
EMP & $-7.87 \mathrm{E}-07$ & $2.63 \mathrm{E}-07$ & -2.996176 & 0.0029 \\
EXP & $-4.20 \mathrm{E}-08$ & $2.81 \mathrm{E}-08$ & -1.493939 & 0.1360 \\
\hline \multicolumn{5}{l}{$\mathrm{l}$} \\
R-squared & 0.886672 & Mean dependent var & 8.680843 \\
Adjusted R-squared & 0.875218 & S.D. dependent var & 5.021717 \\
S.E. of regression & 1.773894 & Akaike info criterion & 4.073494 \\
Sum squared resid & 1183.159 & Schwarz criterion & 4.452055 \\
Log likelihood & -806.2500 & Hannan-Quinn criter. & 4.223190 \\
F-statistic & 77.41560 & Durbin-Watson stat & 0.314079 \\
Prob(F-statistic) & 0.000000 & &
\end{tabular}

Source: Data Processed

These results are similar to research Agarwal and Atri (2015) which adopts a growth model and modifies it to include foreign direct investment, external income, trade openness, market 
size, exchange rates, external debt, and technology as explanatory variables, while proxied poverty where the absolute number of poor people living below the poverty line is used as the dependent variable. From this study, foreign direct investment has been proven effective in reducing poverty in Nigeria. Based on the findings made during the study, it is clear that Nigeria's economic development is highly dependent on the investment climate and thus undoubtedly promotes economic growth.

According to Magombeyi \& Odhiambo (2017), it can be concluded that the positive impact of FDI on poverty alleviation, although the magnitude of the effect varies from sample to sample. Some of the positive contributions of FDI to poverty alleviation are achieved through the spillover effect, job creation, and increased investment capital. Magombeyi \& Odhiambo (2018) used three proxies for poverty reduction, namely: household consumption expenditures, infant mortality rates, and life expectancy rates used in this study to capture the multi-dimensional nature of poverty. By using the autoregressive distribution lag (ARDL) limit test approach, this study reveals that FDI has a positive impact on poverty reduction in the short term and a negative impact in the long term when life expectancy is used as a measure of poverty reduction. When the infant mortality rate is used as a proxy for poverty reduction, the relationship is not significant in the long or short term. The negative impact of FDI on poverty reduction is confirmed in the short term when household consumption expenditure is used as a proxy for poverty reduction, while in the long term, there is an insignificant relationship. So, it can be concluded that Botsnawa might be able to use FDI as a short-term poverty reduction instrument only.

The potential for a very large labor market in Indonesia, in this case, is the abundance of labor in Indonesia, so investors are also interested in investing in Indonesia. This will be a mutually beneficial condition. An example is the form of foreign investment in the form of a company, from the investor side it is profitable because of the availability of labor with relatively inexpensive wages so that the product produced is more, while on the Indonesian side, more workers are absorbed so that opportunities to earn income and get out of poverty is getting higher. The variable number of the working population has a significant and negative impact on poverty. In other words, the higher the working population, the smaller the percentage of the poor. Based on the calculation results, for every 1 percent increase in the number of working people, the poor will decrease by 4.34 percent, assuming the other variables are constant (ceteris paribus). The workforce in Indonesia is highly mobile in every sector of work. In addition, the small-scale business sector also continues its production so that it continues to absorb labor. Raeputranto (2017) states that unemployment is the biggest cause of poverty and needs to be reduced. One way to overcome this is by providing employment and employment opportunities.

The GRDP variable has a significant and negative impact on poverty. In other words, the higher the GRDP, the smaller the percentage of poor people will be. Based on the calculation results, for every 1 percent increase in GDP, the poor population will decrease by 2.37 percent, assuming the other variables are constant (ceteris paribus). GRDP shows the ability of a region to produce goods and services as well as the satisfaction obtained by each resident of these results so that with an increase in GRDP, poverty will be reduced.

Government expenditure variables have a significant and negative impact on poverty. The higher the government spending, the lower the percentage of poor people will be. Based on the calculation results, for every 1 percent increase in government spending, the poor will be reduced by 4.20 percent, assuming the other variables are constant (ceteris paribus). (Todaro, 
1990) states that the government buys goods to meet their daily needs, especially for the benefit of the community, spending on providing health facilities, spending on government employee salaries, and spending on developing infrastructure made for the benefit of the community.

Government spending is allocated to increase agricultural and plantation productivity in meeting the demand for raw materials and staple goods, increasing the supply of consumer goods through the expansion of the small industrial sector which provides additional employment opportunities and increases agricultural capacity. The government can also invest in public works projects and the education and health sectors. Improving education and health will help build human capital so that it will increase development inputs from the technological side. When economic growth increases, foreign investment enters, and employment increases and spreads so that the unemployment rate decreases.

The effect of individual intercept shows that there are differences due to differences in provinces regarding the effect of foreign direct investment on poverty in Indonesia. The intercept for each province is different in the Fixed Effect model, as listed in table 4. If it is assumed that all independent variables in the study do not affect, then Papua is the province that has the highest intercept coefficient value. This indicates that Papua has the highest percentage of poor people among other provinces. This is because Papua has a different standard of living from other provinces. The cost of living to meet daily needs is very high, even when compared to Jakarta as the capital city which incidentally has a high cost of living as well. Besides, the people of Papua, in general, have not received proper education or in other words, there are still many people who do not have higher education, so that bargaining power in labor wages is also low. When the wages received are low while the cost of living is higher, many people are below the poverty line.

Table 4. Estimation of Individual Intercept with Fixed Effect Model

\begin{tabular}{ll}
\hline Fixed Effect & Intercept \\
\hline _ACEH-C & 2.544314 \\
_BALI-C & -6.424860 \\
_BANTEN_C & -1.126632 \\
_BENGKULU-C & 5.423018 \\
_BENGKULU-C & 5.423018 \\
_DIY-C & 2.193924 \\
_GORONTALO-C & -6.358423 \\
_JABAR-C & 23.31467 \\
_JAMBI-C & 0.373609 \\
_JATENG-C & 20.71656 \\
_JATIM-C & 20.38970 \\
_JKT-C & 1.972716 \\
_KALBAR-C & -4.122371 \\
_KALSEL-C & -6.796131 \\
_KALTENG-C & -6.829395 \\
_KALTIM-C & -4.309923 \\
_KALUT-C & -11.31290 \\
_KEPBABEL-C & -8.236715 \\
_KEPRI-C & -4.662484 \\
_LAMPUNG-C & 3.638963 \\
_MALUKU-C & -4.018824 \\
_MALUT-C & -9.552223 \\
_NTB-C & 11.47114
\end{tabular}




$\begin{array}{ll}\text { _NTT-C } & 0.841088 \\ \text { _PAPBAR-C } & -6.211144 \\ \text { _PAPUA-C } & -5.971875 \\ \text { _RIAU-C } & -1.615537 \\ \text { _SULBAR-C } & -2.127383 \\ \text { _SULSEL-C } & -3.373021 \\ \text { _SULTARA-C } & -6.101699 \\ \text { _SULTENG-C } & -1.556407 \\ \text { _SULUT-C } & -5.446533 \\ \text { _SUMBAR-C } & -3.917499 \\ \text { _SUMSEL-C } & 5.959124 \\ \text { _SUMUT-C } & 5.248144\end{array}$

Source: Data Processed, 2020

East Java Province has the second-highest intercept coefficient in Indonesia and the highest in Java Island. This is possible because East Java is the province with the largest number of districts/cities in all of Indonesia. Each district/city has its characteristics. Poverty can be caused by the location where they live in isolation, for example, the Tengger tribe who live in the Tengger mountains of East Java and residents on the island of Bawean. People fail to get the opportunity or access to develop themselves and improve the quality of life, so they are trapped in a situation of deprivation.

DKI Jakarta also has the third-highest intercept in Indonesia. DKI Jakarta is also a province with a high percentage of poor people. This is due to the high cost of living and the large number of migrants who try their luck in the capital without sufficient education and job opportunities available so that many people enter the informal sector or even become beggars. The informal sector is full of income uncertainty and no health insurance.

North Maluku is a province with the lowest intercept coefficient. This indicates that North Maluku has the lowest percentage of poor people among other provinces. The potential of plantations in North Maluku can be developed, namely coconut, cocoa (chocolate), and spice plantations such as cloves. North Maluku's cocoa production has now succeeded in penetrating the export market and bringing foreign exchange for the country as well as being a source of income for the community, thus avoiding poverty. Besides, the tourism potential in North Maluku is also can be developed, such as the MolokuKieRaha Sultanate and the Maluku marine park. It provides opportunities for people to create jobs so that community income can increase.

\section{CONCLUSIONS}

Poverty is a fundamental problem for every developing country including Indonesia that arises because of the inability of some people to organize their lives to a level that is considered human. This problem can hinder economic growth due to the low quality and quantity of resources and living conditions of the people and indicate a lack of economic performance of a country, therefore it needs to be handled seriously. The purpose of this study is to examine the effect of foreign direct investment (FDI) from investors as an alternative funding to the poverty rate of 34 provinces in Indonesia during 2007-2018. According to the theory, this foreign direct investment (FDI) will increase the production of goods and services, so that capital transactions and production factor resources will increase and will increase the income per capita of the community and their standard of living. The results show that there is a negative relationship between FDI and poverty, meaning that the more 
investors who invest in foreign direct investment (FDI), the percentage of poor people will decrease. An increase in FDI by 1 percent will reduce the percentage of poor people by 0.037 percent, assuming other factors are held constant (Ceteris Paribus). This is consistent with the research hypothesis that FDI can contribute to poverty reduction. However, each province certainly feels different effects as a result of the implementation of regional autonomy policies where local governments are given the authority and are required to be creative and innovative in recognizing the potential of their regions to improve the quality of their respective regions. Therefore, this finding can be input and reference for the government to pay more attention to the flow of foreign investment into Indonesia in general and the province in particular so that this funding is more targeted in alleviating poverty in Indonesia. In addition, as a consideration in determining policies for poverty alleviation efforts in Indonesia, especially in each province, it must pay attention to the differences in the potential of each province. This is intended so that the policies taken can be applied to each region according to their respective characteristics. The government must ensure that the investment climate runs well, that people's incomes increase evenly and allocate government spending, reduce foreign debt, and develop the technology. This variable proved statistically significant in reducing poverty in Indonesia.

\section{ACKNOWLEDGEMENTS}

Thank you to Lembaga Penelitian dan Pengabdian kepada Masyarakat (LPPM) Universitas Sriwijaya for funding this research.

\section{REFERENCES}

Aaron, C., 1999. Regionalisation, foreign direct investment and poverty reduction: The case of ASEAN. Asian Development Bank \& OECD Development Centre.

Agarwal, M., \& Atri, P., 2015. Foreign Direct Investment and Poverty Reduction: India in Regional Context RIS Research and Information System for Developing Countries. Research and Information System for Developing Countries, 1-43. Retrieved from http://www.ris.org.in

Ahmad, F., Draz, M. U., Su, L., Ozturk, I., Rauf, A., \& Ali, S., 2019. Impact of FDI inflows on poverty reduction in the ASEAN and SAARC economies. Sustainability (Switzerland). https://doi.org/10.3390/su11092565

Amertapama, H., 2009. Pengaruh Fdi Terhadap Kemiskinan Dan Pengangguran di Indonesia 19932013. Jurnal Paradigma Ekonomika, 1(4), 48-61.

Blomstrom, M., \& Kokko, A., 1997. How Foreign Investment Affects Host Countries. Director.

Blomström, M., Kokko, A., \& Mucchielli, J.-L., 2003. The Economics of Foreign Direct Investment Incentives. In Foreign Direct Investment in the Real and Financial Sector of Industrial Countries. https://doi.org/10.1007/978-3-540-24736-4_3

Chudnovsky, D., \& López, A., 1999. Globalization and Developing Countries: Foreign Direct Investment and Growth and Sustainable Human Development. Policy, (February), 1-35.

Dollar, D., \& Kraay, A., 2004. Growth is Good for the Poor. In Growth, Inequality, and Poverty: Prospects for Pro-poor Economic Development. https://doi.org/10.1093/0199268657.003.0002

Hung, T., 2005. Impacts of Foreign Direct Investment on Poverty Reduction in Vietnam. Discussed Paper, GRIPS, Vietnam, 5(20), 1-24. Retrieved from http://gwww.grips.ac.jp/vietnam/ VDFTokyo/Doc/18TTHungPaper.pdf

IFC., 2000. Generating Private Investment in Fragile and Conflict-Affected Areas.

Ikara., 2003. The Impact of Foreign Direct Investment on Poverty Reduction in the Developing Countries. International Finance and Banking, 4(2), 92. https://doi.org/10.5296/ifb.v4i2.11987

Klein, M., 2003. 2001-WB-FDI and Poverty Reduction. (June 2001). 
Magombeyi, M. T., \& Odhiambo, N. M., 2018. FDI inflows and poverty reduction in Botswana: an empirical investigation. Cogent Economics and Finance, 6(1), 1-15. https://doi.org/10.1080/23322039.2018.1480302

Magombeyi, Mercy T., \& Odhiambo, N. M., 2017. Foreign Direct Investment and Poverty Reduction. Comparative Economic Research. https://doi.org/10.1515/cer-2017-0013

Nachrowi, D., \& Usman, H., 2004. Pendekatan Populer dan Praktis Ekonometrika untuk Analisis Ekonomi dan Keuangan. The Journal of Finance.

Raeputranto., 2017. Impact of Foreign Direct Investment to Poverty Reduction: Indonesia Case. Working Paper, (August), 2-14. https://doi.org/10.13140/RG.2.2.18904.39688

Tambunan, T., 2005. The impact of Foreign Direct Investment on poverty reduction: A survey of literature and a temporary finding from Indonesia. Consultative Meeting on "Foreign Direct Investment and ..., (2), 1-49. Retrieved from http://onlinelibrary.wiley.com/doi/10.1002 /cbdv.200490137/abstract\%5Cnhttp://citeseerx.ist.psu.edu/viewdoc/download?doi=10.1.1.195.48 $4 \&$ rep=rep $1 \&$ type $=$ pdf

Todaro, Michael P., 1990. Economic Development in the Third World, Fourth Edition. Population and Development Review. https://doi.org/10.2307/1972548

Ucal, Meltem S., 2013. Panel Data Analysis of Foreign Direct Investment and Poverty from The Perspective of Developing Countries. Procedia: Social and Behavioral Sciences, 109,1101-1105. https://doi.org/10.1016/j.sbspro.2013.12.594 